at ressonere med velfærdsstaternes fokus på omsorg, tilknytning og sikkerhed. Psykoanalysen kom desuden til at præge de historiske fortællinger om nazismen længe efter anden verdenskrig, og det var først i 1960'erne og 1970'erne, at en stigende kritik af psykologismen medførte, at psykologien $i$ almindelighed og psykoanalysen i særdeleshed mistede sin position i historiografien. Afslutningsvis kunne Pick derfor passende have glimret ved at fuldende sit meget interessante indblik i den psykoanalytiske krigsførelse mod nazismen med en psykohistorisk diagnosticering af motiverne bag vor nære samtids eliminering af idéen om det dybe selv.

Anders Draby

Sorensen

\section{Spinoza, feminisme og en animeret sko}

Hasana Sharp: Spinoza and the Politics of Renaturalization, University of Chicago Press, 2011 , 242 sider, 35 USD.

Inden for moderne fransk filosofi er der en stærk tradition for at beskæftige sig med Spinoza som en filosof, der kan levere begrebslig inspiration for filosoffer med en radikal politisk dagsorden. Folk som Louis Althusser, Gilles Deleuze og Etienne Balibar har således alle ladet sig kraftigt inspirere af den hollandske linseslibers optik - en optik, som ikke tillader nogen sondring mellem Gud og naturen og som samtidig rummer et meget tidligt og interessant forsvar for demokratiet. Hasana Sharps nye bog Spinoza and the Politics of Renaturalization falder solidt inden for denne franske tradition i sit forsøg på at lancere et Spinoza-inspireret politisk perspektiv med fokus på "natur" og "affekter" som alternativ til det Hegelianske anerkendelsesperspektiv, som spiller så central en rolle i mange kritiske politiske teorier i dag. Som titlen indikerer samler Sharps hovedinteresse sig om det politiske potentiale i Spinozas naturbegreb og som en følge heraf, er bogen meget naturligt delt $i$ to 
dele: en første del, som gennemgår tre af kernebegreberne i Spinozas filosofi (natur, affekt og ide) og en anden del, som forsøger at vise hvordan disse ideer leder til en kritik af Judith Butlers anerkendelsesinspirerede feminisme samtidig med at de udviser en slående lighed med grundideerne i Elizabeth Grosz' feminisme.

Den første dels analyse af Spinozas naturbegreb fortolker naturen som et immanent, horisontalt plan hvor alle singulære ting på anti-hierarkisk vis fremtræder som værende lige naturlige - de er alle sammen udtryk for naturens kræfter. Som en konsekvens heraf, giver det ikke mening at tale om noget uden for naturen (noget unaturligt, overnaturligt, undernaturligt osv.) og det er i dette træk ved Spinozas naturforståelse, at Sharp finder et potentiale for en politics of renaturalization. En sådan politik har kritisk brod til flere forskellige sider. For det første vender den sig imod de mange velkendte fremstillinger af kritik som en afnaturalisering, der viser hvordan det angiveligt naturlige $\mathrm{i}$ virkeligheden er historisk og socialt betinget. Ifølge Sharp er en af de afgørende svagheder ved sådanne tilgange, at de ofte er $i$ fare for at blive for voluntaristiske og humanistiske, idet problemerne ofte afgrænses til noget rent socialt og mellemmenneskeligt ( $\mathrm{fx}$ diskurser) hvorved man får indtryk of at det blot er at spørgsmål om at ændre måden vi taler og tænker på. En spinozistisk renaturaliseringspolitik vil derimod, ifølge Sharp, være åben for at se problemerne $\mathrm{i}$ en større økologisk kontekst, samtidig med at den fremhæver hvordan $\mathrm{fx}$ diskurser er rodfæstede $\mathrm{i}$ kropslige affekter. Det øgede fokus på økologiske relationer betyder imidlertid ikke, at Sharp lader sin renaturaliseringspolitik blive identisk med den såkaldte dybdeøkologi. Således kritiserer hun bl.a. Arne Næss' dybdeøkologiske forsøg på at bruge Spinozas tanker til at gøre naturen til en norm, sådan så vi skal respektere naturen og blande os så lidt i dens gang som muligt. Som hun helt rigtigt påpeger, så forudsætter en sådan dybdeøkologisk tankegang implicit, at mennesket er et unaturligt væsen, som forstyrrer og ødelægger naturens gang - stik imod Spinozas ide om at alt er en del af naturen, også mennesket. Her er ingen plads til moraliseren.

Det er der heller ikke i bogens anden del, hvor Sharp på interessant vis først sammenligner Spinozas begreb om begær med Hegels og Butlers forståelse af samme, så bruger et kapitel på at vise hvordan renaturaliseringspolitikken fører til 
en feminisme nogenlunde lig Elizabeth Groszs, for til sidst at skitsere en stærkt Deleuze-inspireret ide om etik som etologi. Alle disse afsnit er for så vidt tankevækkende og oplysende, men man kan ikke undgå at føle, at Spinoza glider lidt i baggrunden, og det rejser et spørgsmål, som uundgåeligt må presse sig på i forbindelse med en bog, som forsøger at reaktualisere en næsten 400 år gammel filosof: hvor meget kan Spinoza egentlig bidrage med i forbindelse med diskussioner af så aktuelle emner som feminisme og økologi? Sharp berører selv spørgsmålet indledningsvis, idet hun omtaler de mange forskellige fortolkninger af Spinoza, som har floreret gennem tiderne, samtidig med at hun giver afkald på at udlægge alle begreberne i hans tænkning og dermed vise sin fortolknings fulde styrke. Hun indrømmer således $\mathrm{fx}$ at det vil være umuligt for hende at forklare hvordan Spinoza kunne mene at selv en sko er animeret (selv om hun personligt finder det helt naturligt at tale på den måde). Samtidig forsøger hun også at dække sig ind ved at citere Pierre Macherey for at enhver fortolkning, som ikke bare er parafrase, må gøre vold mod teksten.

Af alle disse grunde kan man til tider komme i tvivl om hvor meget, der er Spinozas, og hvor meget der er Sharps bidrag. Det rokker dog ikke ved at der, alt i alt, er tale om en ganske interessant bog, som udover de her omtalte emner bl.a. også rummer en interessant fortolkning af Spinozas afgørende betydning for Althusser, en klar analyse af Spinozas uortodokse fortolkning af syndefaldsmyten, samt en udlægning af Spinozas ide om at ytringsfriheden er begrundet i menneskenes manglende evne til at styre deres tunger! Der er således ingen tvivl om at Sharp kender sin Spinoza, og fordi der er tale om et interessant forsøg på at intervenere i nutidige debatter, med Spinoza som inspirationskilde, kan det meget vel tænkes, at bogen også kan tjene som en aktualiserende introduktion til Spinozas filosofi for nytilkomne, samtidig med at den rummer rigeligt med originale Spinoza-læsninger til at give et betydeligt udbytte for den mere erfarne læser.

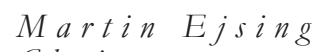

